\title{
The Effect of Quenching Media on the Hardness of AISI 1045 Steel
}

\author{
Mulyadi Mulyadi ${ }^{1}$ Dodi Tafrant ${ }^{1, *}$ Hendradinata Hendradinata ${ }^{1}$ \\ Zainuddin Zainuddin ${ }^{1}$
}

${ }^{1}$ Mechanical Engineering, State Polytechnic of Sriwijaya

*Corresponding author. Email: dodi.tafrant@polsri.ac.id

\begin{abstract}
Steels, as one of the main components of construction requires great strength. Steel can be modified its strength by adjusting the percentage of the amount of its constituent substance composition. Some substances that can be used as a composition in steel include: Iron (Fe), Carbon (C), Phosphorus (P), Manganese (Mn), Sulfur (S), Chrome (Cr), and so on. In addition, according to its use, steel can also be mixed with other substances to form alloy steel. However, most steels are only dominated by a mixture of iron $(\mathrm{Fe})$ and carbon $(\mathrm{C})$ called carbon steel.

In its initial condition, in carbon steel, a mixture of $\mathrm{Fe}$ and $\mathrm{C}$ will form ferrite as the main component of steel. The ferrite contained in the steel will make the steel more ductile, but its hardness value is minimal. In some cases, sometimes steel with a higher hardness value will be needed, with the same percentage of content. For this reason, an effort is needed to increase the hardness value of steel. Efforts to increase the value of this steel hardness can be done by treating the steel with heat treatment. One method of this heat treatment is by quenching. This is done by heating the steel to a temperature of $850^{\circ} \mathrm{C}$, and then rapidly reducing the temperature. With an increase in temperature, the crystal structure of the steel will deform to a ferlite structure. The ferlite structure will deform again slowly into ferrite as the temperature decreases. However, if the temperature is lowered rapidly, the steel structure will deform to martensite instead of unformed ferrite. The martensite phase is harder than ferrite.
\end{abstract}

This research examines the quenching process using several cooling media on AISI 1045 steel. The cooling media used are: Circulated air, water, lubricating oil, and liquid smoke.

Keywords: Carbon steel, AISI 1045, Quenching, Ferrite, Martensite,

\section{INTRODUCTION}

Steel as one of the widely used materials, plays an important role in a construction system. Carbon steel is widely used, especially for making tools, agricultural tools, automotive components and various household needs. Therefore, it is important to have steel with high strength.

For steel, there are at least two ways of heat treatment to increase the value of the mechanical properties of steel. This increase in hardness can be done by heat treatment and plastic deformation. Carbon steel is heated to the austenite formation temperature and then cooled rapidly to form a martensitic structure that has a higher hardness than pearlite or ferrite structures, a process called quenching.

AISI 1045 steel is a medium carbon steel with a carbon composition of $0.43 \%-0.50 \%$. The steel is usually used as an automotive component, such as a gear component in a motor vehicle which in its application experiences friction and pressure. So it requires resistance to wear and hardness (steeldata.info, 2021).

To get the hardness and resistance to wear of steel, obtained through quenching treatment. The purpose of this treatment is to obtain a martensitic structure that is hard and has good wear resistance. In the quenching process, specimens often experience cracking, distortion and non-uniformity of hardness caused by the nonuniform temperature of the cooling solution (Totten, 1993).

In the quenching process heat transfer occurs from the steel to the cooling medium which can be seen by the formation of air bubbles which then continues with the formation of an air sheath on the steel surface. The presence of this air envelope can make the cooling rate 
smaller than the critical cooling rate (Totten, 1993). The decrease in the cooling rate can cause the formation of the martensite phase not to be achieved. Therefore, to shorten the time of formation of the air envelope or increase the cooling rate, a liquid medium is required in the quenching apparatus. With the formation of the martensite phase in the steel structure, it is expected that the steel will become stronger.

In terms of quenching heat treatment of steel metal, there are several studies that have been carried out by previous researchers, including: Nugroho (2005), Pramono (2011), Mersilia, et al (2016), Herlina, et al (2015), Handoyo (2015). ), Astrini (2016), and so on.

In this study, the object under study was AISI 1045 steel with heat treatment to increase the value of the mechanical properties possessed by AISI 1045 steel. The heat treatment applied was quenching treatment (quick cooling) using several cooling media, including: circulating air, salt water, lubricating oil, and liquid smoke.

\subsection{AISI 1045 Steel}

AISI 1045 steel is a medium grade carbon steel with a specific gravity of $7870 \mathrm{~kg} / \mathrm{m} 3$. AISI is a steel standardization of the American Iron and Steel Institute with a code of 1045,1045 indicates that 45 is the carbon content or content of the steel, which is $0.45 \%$. The mechanical properties of AISI 1045 steel are very good, where the AISI 1045 steel has mechanical properties that are capable of welding, machining, as well as good levels of hardness and wear resistance.

In its use, AISI 1045 steel can usually be used for the manufacture of machine components and tooling tools. The application of AISI 1045 steel tends to make components or tools that must have good wear resistance due to the function of the object made so that it can withstand abrasion against dimension reduction due to friction on the object.

The following table are the properties of AISI 1045 steel.:

Table 1. Chemical Composition AISI 1045 Steel

\begin{tabular}{cc}
\hline Chemical Composition & Percent (\%) \\
\hline Carbon & $0,42-0,5$ \\
Iron & $98,51-98,98$ \\
Manganese & $0,6-0,9$ \\
Posport & $\leq 0,04$ \\
Sulfur & $\leq 0,05$ \\
\hline & Ref: azom.com
\end{tabular}

Table 2. Mechanical Properties of AISI 1045 Steel

\begin{tabular}{lc}
\hline Mechanical Properties & Value \\
\hline Brinnel Hardness & 163 \\
Vickers Hardness & 170 \\
Tensile Strength, max & $565 \mathrm{MPa}$ \\
Tensile Strength, Yield & $310 \mathrm{MPa}$ \\
Elasticity & $16 \%$ \\
\hline
\end{tabular}

\begin{tabular}{lc}
\hline Reduction Area & $40 \%$ \\
Modulus Elasticity & $200 \mathrm{GPa}$ \\
Modulus Bulk & $140 \mathrm{GPa}$ \\
Poissons Ratio & 0,29 \\
Modulus Shear & $80 \mathrm{GPa}$ \\
\hline
\end{tabular}

Ref: Azom.com

\subsection{Heat Treatment}

Heat treatment aims as a process to produce a high level of ductility, eliminate internal stress, can also smooth metal grains and can increase the hardness and tensile strength of the metal. Heat treatment is a combination of a heating process and a cooling process on a material. Factors that influence the heat treatment process are the heating temperature or the temperature used, the time required to reach the desired temperature, and the cooling speed when the metal has reached the desired temperature.

Purwano (2011) provides another opinion on this matter. Heat treatment is a process to change the metal structure by heating the specimen in an electrical furnace at a recrystallization temperature for a certain period of time and then cooling it in cooling media such as air, water, salt water, oil and liquid smoke.

Metal properties, especially mechanical properties, are strongly influenced by the microstructure of the metal in addition to its chemical composition, for example a metal or alloy will have different mechanical properties when the microstructure is changed. With heating or cooling at a certain speed, metal and alloy materials will experience changes in their structure. For the purpose of determining the heating temperature of a test, as well as to determine the heat treatment it can use a diagram. The diagram used can make it easier to determine the heating temperature, the diagram is called the $\mathrm{Fe}-\mathrm{C}$ Phase Diagram. The phase diagram is a diagram that shows the relationship between the phase changes that occur during the slow cooling and heating process and the carbon content. (Callister, 2007). The Phase Diagram can be seen in Figure 1.

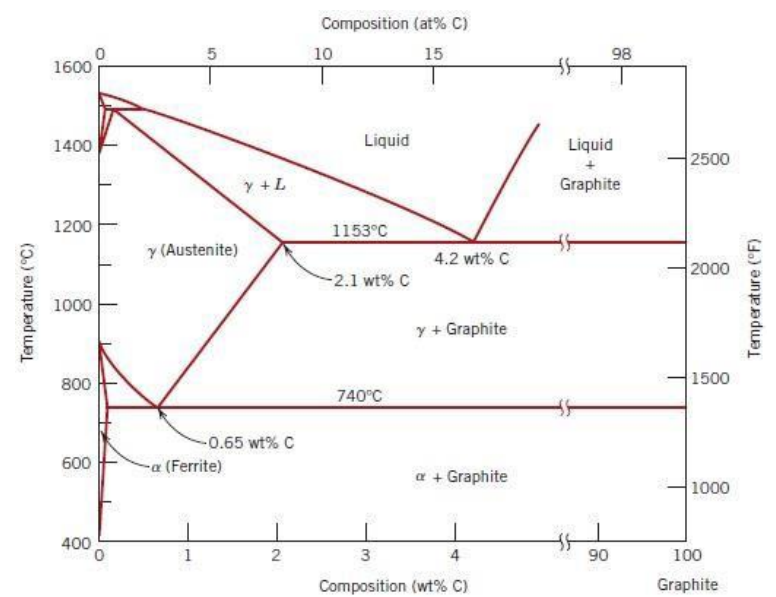

Figure. 1. Fe - C Phase Diagram 


\subsection{CCT Diagram and TTT Diagram}

In addition to the phase diagram, there is a diagram illustrating the relationship between the continuous cooling rate and the phase or structure formed after the phase transformation which is called the Continuous Cooling Transformation (CCT) Diagram. Continuous cooling curves with different cooling rates will produce different phases or steel structures. Each cooling curve shows the beginning and end of the decomposition of austenite to the final steel phase. The CCT diagram for AISI 1045 steel can be seen in Figure 2.

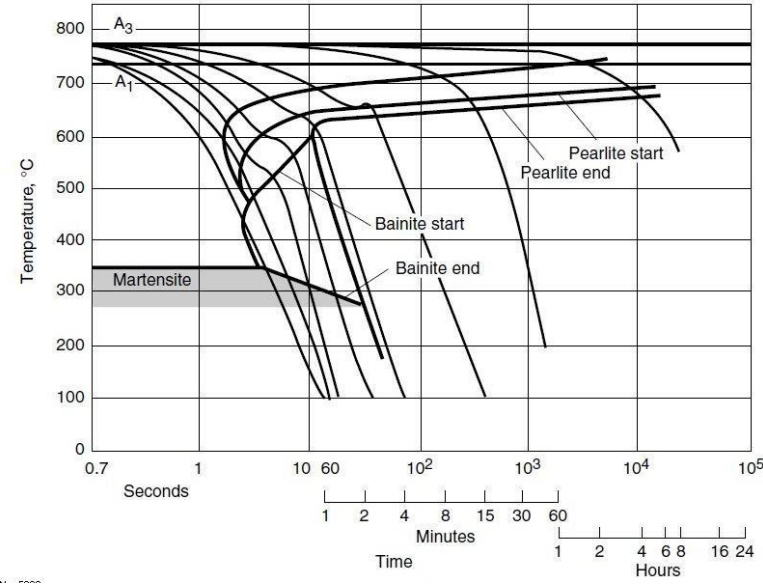

Figure 2. CCT Diagram for AISI 1045 steel

Time Transformation Temperature (TTT) diagram is a diagram that describes the relationship between phases or structures formed after the phase transformation due to changes in temperature and time. The TTT diagram is also known as an isothermal transformation diagram, where isothermal shows a constant temperature. So the changes that occur at a constant temperature. TTT diagram for AISI 1045 steel can be seen in Fig. 3.

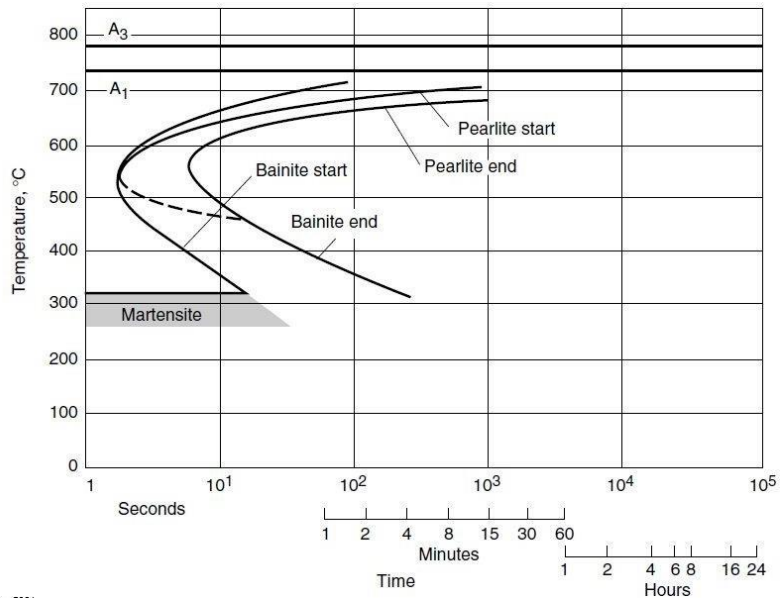

Figure. 3. TTT Diagram for AISI 1045 steel

\subsection{Quenching Process}

The quenching process is a process of heating the metal so that it reaches a homogeneous austenite limit.
To obtain this homogeneity, the austenite needs sufficient heating time. Furthermore, the steel is rapidly immersed in the cooling medium, depending on the cooling speed we want to achieve the hardness of the steel. At the time of rapid cooling the austenite phase did not have time to change to ferrite or pearlite because there was no opportunity for the carbon atoms that had dissolved in the austenite to carry out diffusion movements and cementite was formed, therefore the mertensite phase occurred, this is a very hard phase and depending on the carbon state. Martensite is a metastable phase formed by rapid cooling, all alloying elements are still soluble in the solid state. Heating must be done gradually and slowly to minimize deformation or the risk of cracking. After the austenitizing temperature is reached, the temperature is held for a certain time and then cooled rapidly.

In the quenching process, the cooling medium greatly affects the metal structure and the mechanical ability that can be achieved by the metal. Here are some cooling media that are often used:

\subsubsection{Salt Water}

Salt water has a low viscosity, and its density is greater than other cooling media such as water, diesel, oil, air, so the speed of the cooling medium is large and the cooling rate is faster. Sutiyoko (2014) conducted a quenching study using 5 liters of salt water with a salt content variation of 0 to $30 \%$, the research conducted showed that the higher the salt content, the higher the hardness level obtained.

Another researcher, Kirono (2012), investigated quenching using salt water. The research was conducted using SC45 steel which was heated to a temperature of $850^{\circ} \mathrm{C}$ and then at a temperature of $600^{\circ} \mathrm{C}$, tempering was carried out for 45 minutes. After being heated, the SC45 steel is then subjected to a salt water quenching process and the tests carried out are tensile, hardness and metallographic tests. The conclusion that can be drawn in this study is that the greater the salt content in the cooling medium, the greater the hardness value produced.

Further research was carried out by Yunaidi (2016) by using a salt solution content of $0-25 \%$ of the volume of water used, using SC45 steel with the Vickers method of hardness testing. The highest hardness results were obtained at $25 \%$ salt content of $665.5 \mathrm{VHN}$ and the lowest results at $1 \%$ salt content of $365.88 \mathrm{VHN}$.

\subsubsection{Water}

Water has a large density, but less than salt water, has a low viscosity, the same as salt water. The cooling rate is slower than that of brine. Water produces a cooling rate close to the maximum level. The advantages of water as a cooling medium are: cheap, easily available, easy to dispose of with minimal 
pollution. Water is also effective in removing scaling from quenched steel surfaces. Therefore, water is often used as a quenching medium because it does not cause excessive distortion or cracking. Water is widely used for cooling nonferrous metals, austenitic stainless steels, and other metals that have been heat treated.

Research on water quenching has also been carried out by Restia (2013), where the results obtained when compared with raw materials, the level of hardness of metals that have undergone the quenching process with water has increased significantly, from $43.06 \mathrm{HRC}$ to 59.45 HRC.

Another study was conducted by Berhitu (2014) using low carbon steel, the quenching process was carried out using variations in temperature holding 1 hour, 2 hours, 3 hours and 4 hours. The results of the hardness test using the brinell method were 120.375 $\mathrm{HRB}$, an increase from the raw material, which was 77.6 HRB. It can be concluded that quenching with water media can increase the mechanical strength of low carbon steel significantly.

\subsubsection{Lubricating Oil}

Lubricating oil has the highest viscosity value compared to other cooling media. In addition, the lubricant has a low density, so the cooling rate is relatively slower.

Quenching using lubricating oil media has been studied by Bahtiar (2014), where cooling using lubricating oil media, metal hardness has increased from $62.3 \mathrm{HRC}$ to $63.7 \mathrm{HRC}$.

Another study was conducted by Sumiyanto (2012) using medium carbon steel SNCM 447, where the steel was heated to a temperature of $900 \mathrm{oC}$ and then quenched using lubricating oil media. Hardness testing was carried out using the Vickers method, and the results of the hardness value of SNCM 447 steel of 504 VHN increased significantly from 216 VHN. So it can be concluded that the effect of oil media can increase the hardness of SNCM 447 steel.

\subsubsection{Circulating Air}

Air is basically rarely used as a cooling medium in the quenching process. This is because air is a gas fluid. But basically, the quencing process is done by adjusting the speed of decreasing the temperature of the specimen. This can also be done by increasing the speed of the air flow so that the speed of heat transfer from the specimen to the air will be faster due to the increase in the speed of convection heat transfer from the specimen to the flowing air.

Research on quenching using air was carried out by Basori (2018) on hardfacing low carbon steels. The research that was conducted gave an increase in the hardness test value of 15 VHN compared to the specimens that were not quenched. In the microstructure there is also the formation of bainite as a result of the quenching process.

Saefuloh, et al (2018) conducted a study on lateritic alloy steels treated with tempering and quenching. The test is carried out by quenching the specimen which is then subjected to tempering treatment at a temperature of $100^{\circ} \mathrm{C}$ to $300^{\circ} \mathrm{C}$. The results obtained are that the specimens quenched with air will form ferrite and ferrite structures which will provide better ductility. The hardness value of the air-quenched specimen increased by $20 \mathrm{VHN}$. In addition, the specimens quenched with air showed ductile fracture when the impact test was carried out.

\section{RESEARCH METHODOLOGY}

The research was conducted by collecting data on specimens treated with the quenching process, and examining the effects of these treatments on the hardness of the specimens.

\subsection{Tools And Materials}

There are several tools and materials used in this study. The tools and materials used include:

1. AISI 1045 Steel

2. Furnace tools

3. Fan

4. Lubricating Oil

5. Salt Water

6. Liquid Smoke

7. Rockwell Hardness Tester

\subsection{Research procedure}

The research procedure has several stages, starting from making test specimens, treating specimens, testing specimens, and taking test data. The research procedures are:

1. Manufacture of AISI 1045 steel specimens by cutting the AISI 1045 material using a cutting machine according to dimensions based on the test equipment.

2. Treatment of AISI 1045 steel specimens.

The stages of treatment are:

a. Turn on the furnace and calibrate the furnace using a thermocouple to avoid temperature errors.

b. AISI 1045 steel that has been cut is heated or put into the furnace to a temperature of $850 \mathrm{oC}$.

c. Then hold the steel at $850 \mathrm{oC}$ for 25 minutes.

d. Then the steel is quenched.

e. Place some AISI 1045 steel specimens on the table, and give them airflow.

f. Put some AISI 1045 steel specimens in the brine. Lift the AISI 1045 steel and dry it. 
g. Put some AISI 1045 steel specimens into the lubricating oil. Lift the AISI 1045 steel and dry it.

h. Put some AISI 1045 steel specimens into the liquid smoke. Lift the AISI 1045 steel and dry it.

3. Testing of AISI 1045 steel specimens using Rockwell method.

The testing stages are:

a. Set the load of the test equipment that is equal to $980 \mathrm{~N}$

b. Install a 1/16" steel ball indenter on the test equipment, a 1/16" steel ball indenter is used because the test uses a red scale

c. Putting the AISI 1045 steel specimen on the test table of the tool

d. Then adjust the handle of the test tool until the indenter touches the surface of the specimen

e. Calibrate test equipment to zero

f. Turn the handle until the needle of the minor scale shows the number 3

g. Then pull the load lever, wait for 10 seconds

h. Pull back the load lever

i. Check the resulting hardness value and record

j. Lower the anvil handle until the indenter no longer touches the specimen

k. Repeat steps with different points

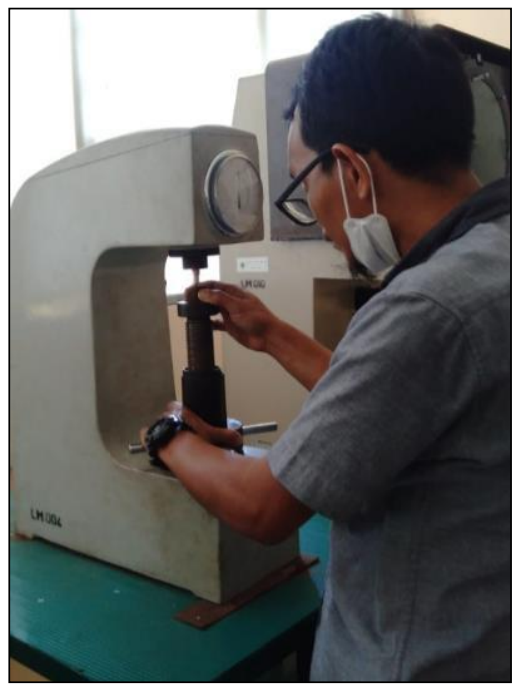

Figure. 4. Hardness Testing

\section{THE RESULT}

Based on the research conducted, the following results were obtained.

Hardness testing uses the Rockwell method which aims to determine the hardness of a material against a diamond indenter that is emphasized on the surface of the test object. Each sample was tested at random at 5 points. The results of testing the hardness value carried out by the Rockwell C method with a loading of $980 \mathrm{~N}$ obtained the data shown in Table 3.
Table 3. Hardness Test Result

\begin{tabular}{lc} 
Heat Treatment & Hardness (HRc) \\
No treatment & 39.35 \\
Circulating Air & 32.35 \\
Lubricating Oil & 51.98 \\
Salt Water & 63.76 \\
Liquid Smoke & $\underline{65.40}$ \\
\hline
\end{tabular}

Table 3 shows the average of the results of the hardness test using the Rockwell method on all specimens. For the specimens that have not been heat treated, the hardness value obtained is $39.35 \mathrm{HRc}$. The specimens that were quenched with circulating air, the hardness of the specimens decreased to $32.55 \mathrm{HRc}$. This is because in circulating air, the heat treatment is more closer to normalizing heat treatment. The rate of heat loss that occurs in the specimen becomes slower.

Different results were shown in specimens quenched with other fluids. In specimens quenched with lubricating oil, there was an increase in the hardness value to $51.98 \mathrm{HRc}$. Meanwhile, the higher hardness value was shown by the specimens quenched with salt water to $63.76 \mathrm{HRc}$. The highest increase in hardness values was shown by specimens quenched with liquid smoke. The hardness value obtained is $65.40 \mathrm{HRc}$. Fig. 6 shows the change in hardness of AISI 1045 steel before and after the quenching process.

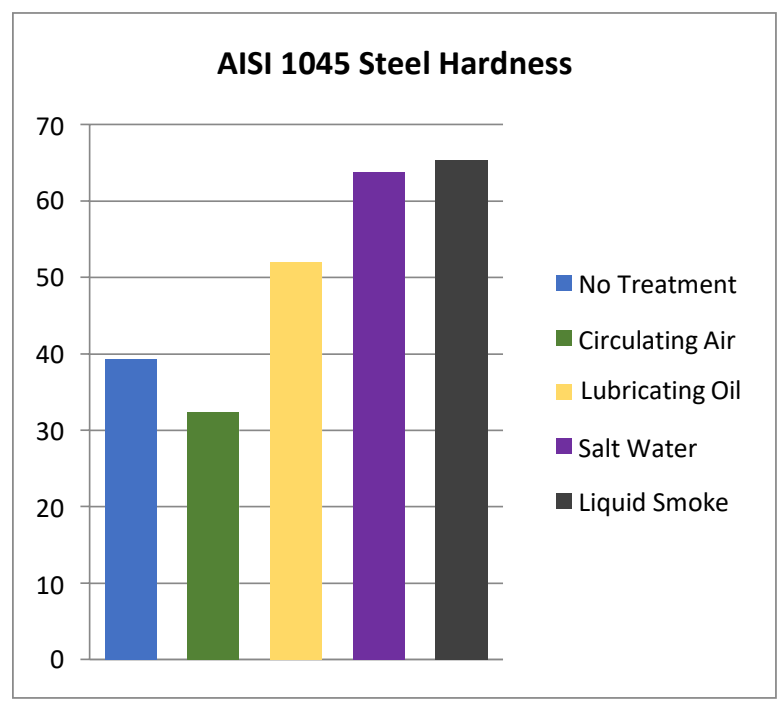

Figure 5. AISI 1045 steel before and after heat

treatment Salt water and liquid smoke media have a fast

cooling rate, resulting in a harder bond because the surface of the specimen will bind to charcoal so that there is more martensite formation.

\section{CONCLUSION}

This study shows the effect of heat treatment on the hardness value of AISI 1045 steel. Based on the results of research and testing that have been carried out and discussion of the quenching process on AISI 1045 steel 
on the hardness value, the following conclusions can be drawn:

1. Quenching using lubricating oil, salt water, and liquid smoke can increase the hardness to a higher level, while quenching using circulating air media causes a decrease in the hardness value of AISI 1045 steel to $32.35 \mathrm{HRc}$ from the initial hardness value of $39.35 \mathrm{HRc}$.

2. Quenching using liquid smoke media gave the highest hardness value to $65.40 \mathrm{HRc}$. This means that there is an increase of $29.05 \mathrm{HRc}$.

\section{REFERENCES}

[1] Astrini, Indah R., Pulung Karo Karo, Yayat Iman Supriyatna. 2016. "Pengaruh Heat Treatment Dengan Variasi Media Quenching Air Dan Oli Terhadap Struktur Mikro Dan Nilai Kekerasan Baja Pegas Daun AISI 6135”. Jurnal Teori dan Aplikasi Fisika, Vol. 4, No. 2, hal: 195-200

[2] Azom.com (accessed on March 27, 2021)

[3] Bahtiar. 2014. "Pengaruh Media Pendingin Dengan Minyak Pelumas SAE 40 Pada Proses Quenching Dan Tempering Terhadap Ketangguhan Baja Karbon Rendah”. Jurnal Mekanikal Vol. 5 No. 1 : Januari 2014. Hal : 455463

[4] Berhitu, Pieter. 2014. "Pengaruh Holding Time Dan Quenching Terhadap Kekerasan Baja Karbon ST37 Pada Proses Pack Carburizing Menggunakan Arang Batok Biji Pala (Myristica Fagrans)" Teknologi: Jurnal Ilmu-ilmu Teknik dan Sains. Vol. 11. No. 1. April Hal: 54-67

[5] Callister, William D., Jr. David G. Rethwisch. 2007. "Material Science and Engineering: An Introduction $7^{\text {th }}$ Edition”. John Wiley and Sons, Inc., USA

[6] "Chain Sprocket: Aplikasi Baru di Segmen Otomotif yang Menjanjikan”. KS Review Vol V No 2. 2004

[7] Handoyo, Yopi. dkk. 2015. "Pengaruh Quenching Dan Tempering Pada Baja Jis Grade S45c Terhadap Sifat Mekanis Dan Struktur Mikro Crankshaft". Jurnal Ilmiah Teknik Mesin, Vol. 3, No. 3, hal: 102-105

[8] Herlina, Firda,. M.Firman, Edi Yani Fazri. 2015. "Mengetahui Nilai Kekerasan Dan Struktur Mikro Dari Bahan Baja Pegas Daun Akibat Perlakuan Panas Dengan Temperature Dan Pendingin Yang Bervariasi”. Info Teknik, Vol. 16, No. 1, hal: $75-84$
[9] Kirono, Sasi. 2012. "Pengaruh Proses Tempering Pada Baja Karbon Medium Setelah Quenching Dengan Mediaoli Dan Air Garam (Nacl) Terhadap Sifat Mekanis Dan Struktur Mikro”. SINTEK. Vol. 5. No. 1. Hal 36-47

[10] Mersilia, Anggun., Pulung Karo Karo, Yayat Iman Supriyatna. 2016. "Pengaruh Heat Treatment Dengan Variasi Media Quenching Air Garam dan Oli Terhadap Struktur Mikro dan Nilai Kekerasan Baja Pegas Daun AISI 6135” Jurnal Teori dan Aplikasi Fisika, Vol. 4, No. 1, hal. $175-180$

[11] Nugroho, Sri,. Gunawan Dwi Haryadi. 2005. "Pengaruh Media Quenching Air Tersirkulasi (Circulated Water) Terhadap Struktur Mikro Dan Kekerasan Baja AISI 1045”. Rotasi, Vol. 7, No. 1, hal: $19-23$

[12] Pramono, Agus. 2011. "Karakterisrik Mekanik Proses Hardening Baja Aisi 1045 Media Quenching Untuk Aplikasi Sprochet Rantai". Jurnal Ilmiah Teknik Mesin: Cakra M, Vol 5, No. 1, hal: $32-38$

[13] Restia, Dina. 2014. "Pengaruh Proses Pemanasan Dengan Variasi Media Pendinging Terhadap Nilai Kekerasan Dan Struktur Mikro Pada Baja Karbong Sedang”. Jurnal Teori dan Aplikasi Fisika. Vol. 02, No. 01 Hal: 45-56

[14] Saefuloh, Iman,. Haryadi. Abdurrofi Zahrawani. Bintang Adjiantoro. 2018. "Pengaruh Proses Quenching Dan Tempering Terhadap Sifat Mekanik Dan Struktur Mikro Baja Karbon Rendah Dengan Paduan Laterit”. Flywheel: Jurnal Teknik Mesin Untirta, Vol. 4, No. 1. Hal: 56-64

[15] Steeldata.info (accessed on March 27, 2021)

[16] Sumiyanto. 2012. "Pengaruh Proses Hardening Dan Tempering Terhadap Kekerasan Dan Struktur Mikro Pada Baja Karbon Sedang Enis SNCM 447”. Naskah Jurnal UPN. Vol. 2. No. 1. Hal: 87-92

[17] Sutiyoko. 2014 "Perubahan Sifat Mekanik Material Karena Perbedaan Konsentrasi Larutan Garam Nacl Pada Proses Quenching”. Jurnal Foundry. Vol. 4. No. 1. April 2014. Hal 25-28

[18] Totten, GE, Bates, CE, Clinton, NA, 1993. "Handbook of Quenchant and Quenching Technology, ASM International”, USA

[19] Yunaidi. 2016. "Pengaruh Jumlah Konsentrasi Larutan Garam Pada Proses Quenching Baja Karbong Sedang S45C”. Jurnal Mekanika dan Sistem Termal. Vol. 1. No. 3 